Chirurgia (2017) 112: 301-307

No. 3, May - June

Copyright@ Celsius

http://dx.doi.org/10.21614/chirurgia.112.3.301

\title{
Extension of Hepatic Resection Ameliorates Survival in Patients with Type Illa or IIIb Klatskin Tumors Despite Surgical Complications
}

\author{
Radu Razvan Scurtu, George Dindelegan, Vasile Bintintan, Radu Drasovean, Raluca Apostu, Constantin Ciuce
}

First Surgical Clinic, University of Medicine and Pharmacy “Iuliu Hatieganu “Cluj-Napoca, Romania

Corresponding author: George Dindelegan, MD

University of Medicine and Pharmacy

"Iuliu Hatieganu" Cluj-Napoca

First Surgical Clinic

3-5 Clinicilor street

400006 Cluj, Romania

E-mail: george.dindelegan@gmail.com

Received: 20.03.2017

Accepted: 10.04 .2017

\section{Rezumat}

Rezectiile hepatice extinse ameliorează supraviețirea pacienților cu tumori Klatskin tip III sau IV în pofida complicaților postoperatorii

Introducere: Hepatectomiile majore efectuate pentru colangiocarcinom hilar (HC) sunt încă asociate cu o morbiditate şi mortalitate postoperatorie crescute. Scopul acestei lucrări a fost de a evalua dacă şi cum este influențată supraviețuirea pacienților cu HC tip III si IV conform clasificării Bismuth-Corlette, de complicațiile semnificative survenite după hepatectomii extinse.

Material şi metodă: Au fost evaluate retrospectiv dosarele medicale ale pacientilor cu hepatectomii majore pentru $\mathrm{HC}$ urmate de complicații. Doar pacienții cu urmărire postoperatorie completă au fost incluşi în studiu. Au fost urmărite morbiditatea şi mortalitatea postoperatorie, durata de spitalizare, supraviețuirea şi intervalul liber de boală.

Rezultate: Doar cinci pacienți au corespuns criteriilor de includere în studiu. Trei pacienți au necesitat reintervenție chirurgicală, cu un deces pe durata spitalizării. Doi pacienți sunt încă în urmărire, ceilalți decedînd prin recidivă tumorală, după un interval liber de boală de 36 , respectiv 49 de luni. Durata medie actualizată de supraviețuire a fost de 30 luni, iar intervalul liber mediu de boală a fost de 26 luni.

Concluzii: La pacienții cu HC hepatectomiile extinse au un beneficiu clar pentru supraviețuire, dar se asociaza cu o morbiditate şi mortalitate postoperatorie crescute. Tratate cu succes, complicațiile postoperatorii nu influențează semnificativ supraviețuirea pe termen lung. 
Cuvinte cheie: colangiocarcinom hilar, hepatectomie, complicații postoperatorii, supraviețuire

\begin{abstract}
Background: Major hepatectomies for hilar cholangiocarcinoma (HC) are associated with high rates of morbidity and mortality. We aimed to evaluate how and if surgical complications related to extended hepatectomies for HC type III and IV according to Bismuth-Corlette classification influence patients' long-term survival.

Methods: The files of all patients with major hepatectomy for $\mathrm{HC}$ and postoperative complications were retrospectively reviewed. Only patients with a complete postoperative follow up have be taken into account for the study. Postoperative morbidity and mortality, length of hospital stay (LOS) as well as overall survival (OS) and disease free survival (DFS) were recorded.

Results: Five patients have been found to respond to all inclusion criteria. Three of them required re-operation with one in hospital death. Two patients are still alive and two other died because of the tumor recurrence with a DFS of 36 and 49 months respectively. The actuarial mean OS for the group was 30 months and the actuarial DFS was 26 months.

Conclusions: In patients with HC, extensive resections bring a clearly benefit in terms of survival, even though there is an increase in postoperative morbidity and mortality. However, postoperative complications, if managed susccesfully do not interfere with the long-term survival.
\end{abstract}

Key words: hilar cholangicarcinoma, hepatectomy, postoperative complications, survival

\section{Introduction}

Cholangiocarcinoma of the hepatic hilum or hilar cholangiocarcinoma (HC) is also known as Klatskin tumor (1) and accounts for $40 \%$ to $60 \%$ of all cholangiocarcinomas (2). It has a silent evolution, therefore the diagnostic is usually late and the treatment difficult. Patients diagnosed wih Klatskin tumors usually present with jaundice, weight loss and abdominal discomfort $(3,4)$. Complete surgical resection remains the only curative treatment but due to the tumor location, close to the major hepatic vessels and liver parenchyma, free distal margins are difficult to achieve. Therefore, complex hepatic resections with bile duct excision and even sometimes, vascular resections are needed in order to achieve a free distal margin which ensures a radical oncologic result (5). Even though a radical resection could be achieved, which ensures the best chances for a long-term survival in patients with Klatskin tumors, the recurrence rates are still high $(6,7)$.

However, despite an important improve- ment in the surgical technique and postoperative care, major hepatectomies for $\mathrm{HC}$ are still associated with high rates of morbidity and mortality. Even in tertiary and high volume centers morbidity can reach an incidence of more than $40 \%$ while reported mortality still remains in the neighborhood of $10 \%(8,9,10)$.

In this study we aimed to evaluate how and if surgical complications related to extended hepatectomies for Klatskin cholangiocarcinoma type III and IV according to BismuthCorlette classification (11) have an influence on patients' survival.

\section{Patients and Methods}

We have selected for this retrospective study patients with a diagnosis of Klatskin tumor stage III or IV according to Bismuth Corlette classification (11) in whom a major hepatectomy had to be performed. We defined as major hepatectomy the resection of at least three liver segments while the hepatectomy type was defined according to the Brisbane terminology (12). Furthermore, we selected only the files of 
patients with a $\mathrm{R} 0$ resection, namely those with a negative hepatic and biliary margin on the final pathologic examination of the resected specimen. Moreover, we took into consideration only the files of patients with a completely documented postoperative follow-up. Finally, among the defined group of patients, we kept for further analysis only patients with significant postoperative complications directly related to surgery, which results at the end, into a restricted number of only five patients that had fulfilled all the inclusion criteria for this study. The diagnosis of HC was based on the MRI tumor characteristics in all patients. Only one patient, with stage IV disease, who initially was not considered as a candidate for surgery, had a preoperative percutaneous biliary drainage of the right hepatic lobe bile ducts. All patients presented with jaundice and hypoalbuminemia and they all underwent aggressive preoperative nutrition started for at least 7 days before surgery.

\section{Surgical Technique}

All operations where performed through a right subcostal incision extended to the left of the midline. Intraoperative liver ultrasonography was routinely performed to assess resectability. Laparoscopic exploration has been done in our department in few patients with Klatskin

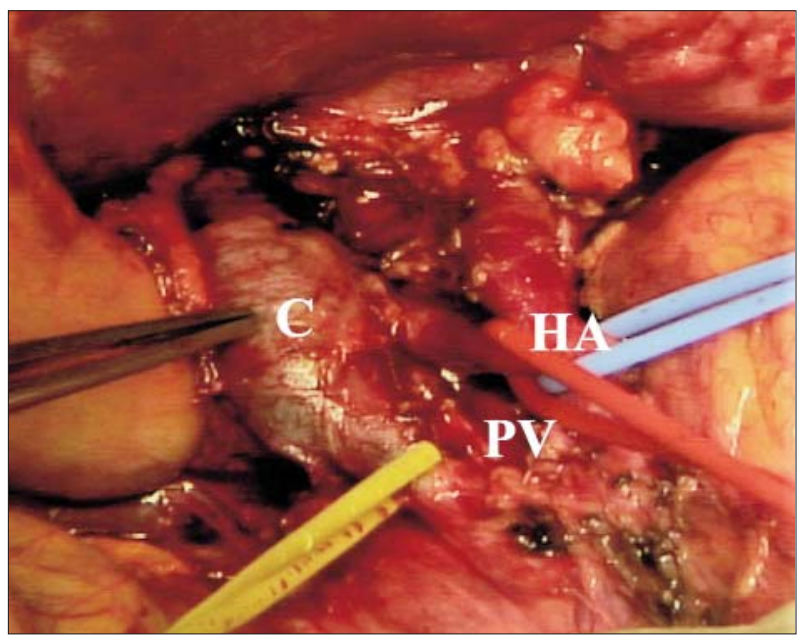

Figure 1. Lymphadenectomy in the liver hilum. $\mathrm{C}=$ Choledocus; $\mathrm{PV}=$ Portal Vein; $\mathrm{HA}=$ Hepatic artery tumors but none of the patients included in the present study underwent this procedure.

All patients underwent caudate lobe resection, extended lymphadenectomy (Fig. 1) of the hepatic hilum and along the common hepatic artery up to the root of the coeliac axis and Roux en Y hepaticojejunostomy (Fig. 2), Biliary duct reconstruction to a common orifice was performed in three patients, and included in two patients two segmental ducts, while in the third patient the biliary reconstruction had to include three segmental ducts. Patients with Klastkin tumors type IV underwent extended left hepatectomy but the liver remnant volume was still appreciated at around 50\%. One of these two patients, had a preoperative suspicion of tumor vascular invasion, which has confirmed during surgery. Therefore, he underwent a resection of the right hepatic artery with end-to end reconstruction, as well as portal vein wedge resection and primary closure. Patients with stage IIIB Klatskin tumor underwent a left hepatectomy.

\section{Outcome Evaluation}

Operative mortality was defined as death before discharge from hospital or within 90 days after surgery. We defined postoperative morbidity as any deviation from the normal postoperative course, prolonging or complicating the patient

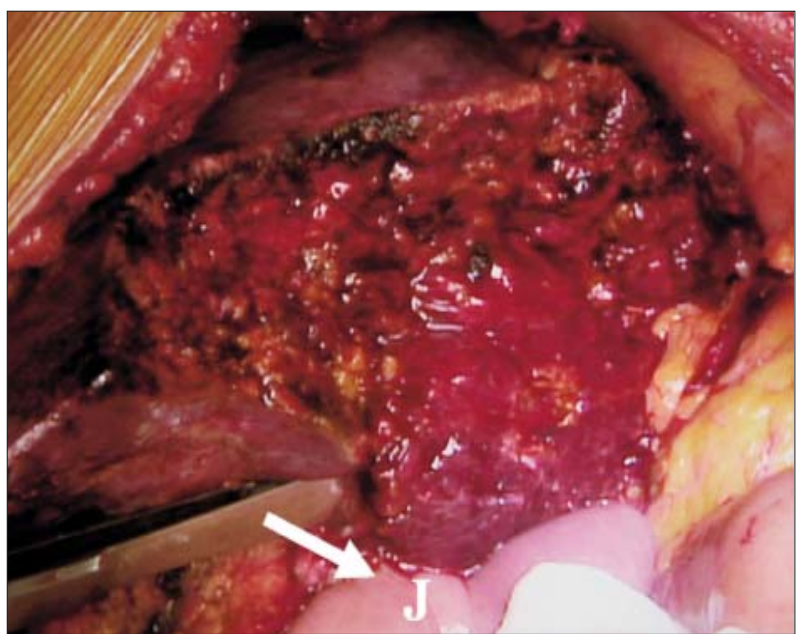

Figure 2. Hepaticojejunostomy (arrow); $\mathrm{J}=$ Jejunum 
recovery. Major morbidity was considered as any grade III or higher surgical complication according to Clavien -Dindo classification (13). We also recorded the tumor stage according to The American Joint Committe on Cancer (AJCC) seventh edition (14) and the tumor grade according to the method of Broder (15), as well as the overall survival (OS) and the disease free survival (DFS). Since all patients had been admitted well before surgery and underwent an intensive preoperative nutrition program in order to ameliorate their metabolic status, we decided to take into account only the postoperative hospital length of stay ( $\mathrm{p} \mathrm{LOS}$ ).

\section{Results}

All patients were men with a mean age of 61 years and 4 months (range from 47 to 69) and all of them presented initially for jaundice and weight loss.

Two patients had a stage IV tumor according to the MRI (Fig. $3 A, B$ ) while the three others had a stage IIIB. In one patient the MRI but especially the CT scan and the ultrasound endoscopy suggested a tumor invasion of the portal vein main trunk and of the common hepatic artery. Laboratory tests confirmed the cholestasis in all patients, with a mean total bilirubinemia at admission of $5.3 \mathrm{mg} / \mathrm{dl}\left(3.2^{-}-8.7\right)$ and also hypoalbuminemia with a mean value of $3.2 \mathrm{~g} / \mathrm{dl}$ (2.1-3.8). After intensive preoperative nutrition, the mean albuminemia prior to surgery reached normal values in all patients with a mean value of $4.6 \mathrm{~g} / \mathrm{dl}$.

The mean operative time was 317 minutes (232-412 minutes) and the mean blood loss was $420 \mathrm{ml}(280-730 \mathrm{ml})$. Re-resection of the hepatic parenchyma and biliary ducts had to be performed in three patients two with tumors type IIIB and one with type IV (B-C classification) in order to obtain tumor free margins. The operative time recorded for the patient with vascular invasion, and in whom arterial and portal resection and reconstruction had to be performed, was only 28 minutes longer than the mean time.

All patients had a histologically proven cholangiocarcinoma. Three of these tumors were moderately differentiated (G2), one was well differentiated (G1) and one poorly differentiated (G3). The mean tumor diameter was $5 \mathrm{~cm}(3.2-7 \mathrm{~cm})$, but the $\mathrm{T}$ stage was $\mathrm{T} 2$ in 3 patients. We recorded also a T1 stage and a also a T4 stage in the patient in whom vascular resection had to be associated. The

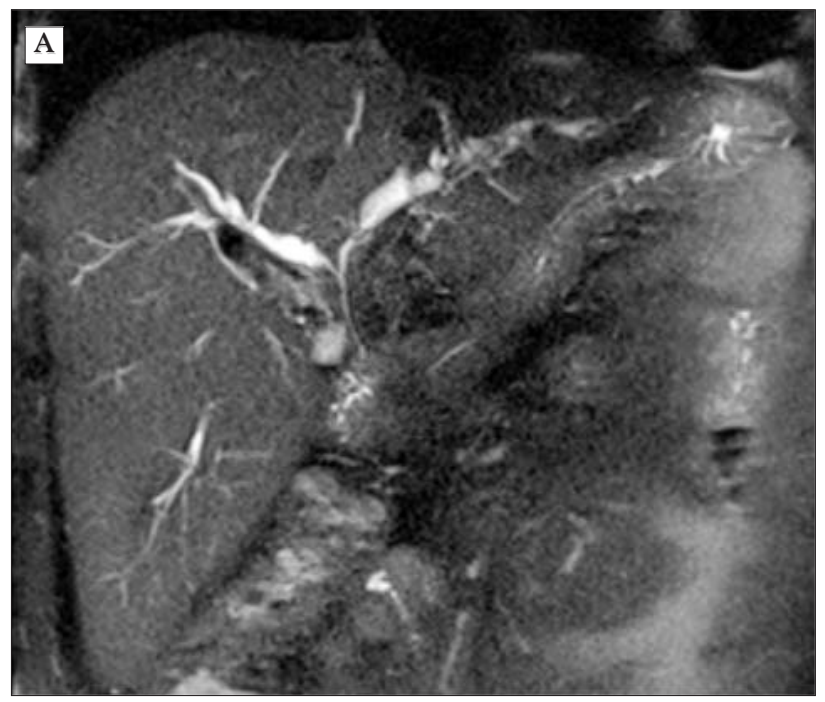

Figure 3. (A) MRI aspect showing an stage IV HC

(B) MRI cholangiogram with complete amputation by the tumor of the right and left bepatic ducts (arrow) MRI aspect of stage IV HC

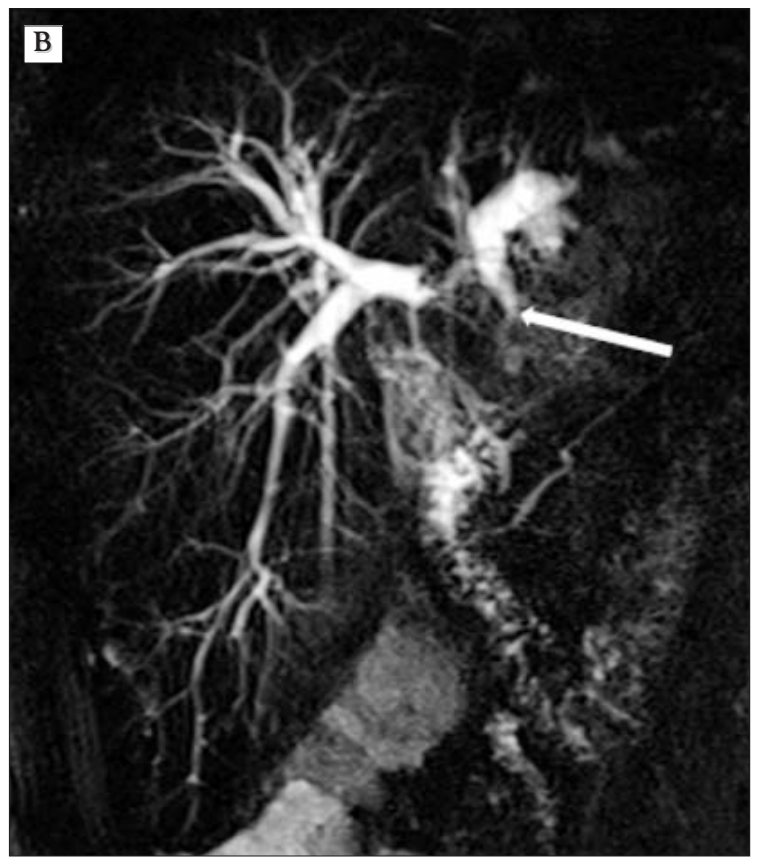


mean number of examined lymph nodes was $7.8(6-14)$ with only 2 metastatic lymph nodes found in the same specimen (G2 cholangiocarcinoma, stage IIIB).

Morbidity directly related to surgery is depicted in Table 1.

Three patients underwent reoperation, all of them with complications of grade III or higher. The patient with biliary fistula underwent only aspiration of the bilioma and a replacement of a drain tube near the hepaticojunostomy with a postoperative uneventful course. The patient with late bleeding secondary to an eroded mesenteric vessel of the first jejunal loop by the drain underwent only local hemostasis and afterwards he had no further complications. The third patient, with vascular resection associated to hepatectomy and bile duct resection, presented important bleeding 24 hours after the operation and abdominal Doppler ultrasound revealed a complete portal thrombosis. The patient underwent portal thrombectomy but the postoperative course was complicated by liver failure and finally by in hospital death on the $4^{\text {th }}$ postoperative day.

The two patients with grade II complications were managed conservatively. In the patient with biliary fistula the conservative management was possible because of to the preoperative drainage of the right liver, which was kept in place even after surgery. The mean postoperative LOS was 25 days with the shortest hospital stay (6 days) for the patient died in hospital and the longest stay for the patient with biliary fistula (complication grade IIIB) which required surgical drainage.

All surviving patients underwent postoperative chemotherapy, with two of them (both stage IIIB) alive at 4 and 15 months respectively, without recurrence. Two patients with stages IIIB an IV survived for 46 and 55 months respectively, with a median OS of 50,5 months. These two patients had a DFS of 36 and 49 months respectively. The site of initial recurrence was the liver and the retroperitoneal lymph nodes respectively. The actuarial mean OS for the group was 30 months and the actuarial DFS was 26 months.

\section{Discussions}

Hilar cholangiocarcinoma is a rare neoplasm, but it accounts for 40 to $60 \%$ of all cholangiocarcinomas (2). The tumor arises at the biliary confluence or the right or left hepatic ducts and it was characterized as a slow-growing and late metastasizing tumor (16). However, due to its anatomical location, HC spreads towards the liver parenchyma and along the major vascular structures, namely the portal vein and the hepatic arteries. This tumor behavior has as a result a great incidence of locally advanced stages at presentation which makes it very challenging for an effective management.

Surgical resection is the only therapeutic option that offers a possibility of cure. Several reports showed a significant improvement in the resectability rate and survival with more aggressive surgical approach including extended hepatectomy and even vascular resection. These reports have shown that hepatic and biliary negative resection margins are an independent prognostic factor for long-term survival $(3,17,18,19,20)$. The counterpart of the oncologic favorable prognosis in HC favored by the extended resections was an increased postoperative mortality and morbidity. Even in tertiary referral centers with high experience in liver surgery, the reported mortality range between 1 to $10 \%$ while morbidity overpass $40 \%$ $(8,21,22,23)$. The most common postoperative

\begin{tabular}{|c|c|c|c|c|c|}
\hline & & \multirow{2}{*}{$\frac{\text { Tumor type }}{\text { ॥ }}$} & & \multirow{2}{*}{ Grade } \\
\hline & & Surgery & Morbidity & \\
\hline & & IIIB & Left hepatectomy & Intraabdominal collection with fever and leukocytosis & II \\
\hline \multirow[t]{4}{*}{ Table 1.} & Morbidity directly & IIIB & Left hepatectomy & Biliary fistula & IIIB \\
\hline & related to surgery & IIIB & Left hepatectomy & Haemorhage by drain tube & IV \\
\hline & according to & IV & Extended left hepatectomy & Portal thrombosis & V \\
\hline & classification & IV & Extended left hepatectomy & Biliary fistula & $\|$ \\
\hline
\end{tabular}


complication were wound infection and bile leakage as we seen also in our small group and depicted in table $1(18,24,25)$. In our series the only patient with preoperative biliary drainage developed a biliary fistula, but because the biliary drain was kept in place after surgery this complication could be managed conservatively. Farges et al. (8) found that after left hepatectomies for $\mathrm{HC}$ with preoperative percutaneous biliary drainage there is a significant increase in postoperative sepsis, but fortunately this was not the case for our patient.

Among the most frequent reported causes of mortality were intraabdominal bleeding and liver failure $(26,27)$. Liver failure, could be at his turn, consecutive of both the $\mathrm{HC}$ with preoperative severe obstructive jaundice and cholangitis and extended liver resection (28). All patients included in our series had a liver remnant volume of around 50\% which was preserved bearing in mind the risk of postoperative liver failure. In fact, only one patient died consecutive to this complication which at his turn was determined by portal thrombosis. Miyazaki et al showed that portal vein thrombosis after portal resection occur more frequently after hepatectomy than after pancreatectomy, and also that the restoration of portal vein blood flow was more efficiently achieved when re-operation was performed within 3 days after surgery (29). In our patient portal thrombectomy was performed 24 hours after the first operation, but the patient still developed liver failure and subsequently died 4 days later.

Baton et al were among the few to find a correlation between postoperative morbidity and survival after hepatectomies for HC (23). However, in multivariate analysis this correlation was not statistically significant and the reported mean OS was 32 months. Hartog in a review of more than 4000 patients with $\mathrm{HC}$ reported a median OS after surgery of 34 months ranging between 13 and 64 months (4), while for patients with R0 resections median OS of 60 to 65 months are reported $(20,30)$. In our patients despite severe complications the actuarial mean OS was 30 months, while for the two patients for whom the follow-up had to be ended because of the natural evolution of the disease the median OS was 50 months. These patients had an R0 resection but they also had a negative lymph node status and a lymph node count more than 3 , which all have been reported to be independent predictors for favorable survival $(6,31)$. All patients in the study had relatively big tumors with a mean diameter of $5 \mathrm{~cm}$, but the HC tumor diameter was not shown to predict survival on multivariate analysis (24). However, an earlier $\mathrm{T}$ stage has been shown to impact survival but having no relationship to tumor size (32). In our series, the two patients with a median survival of 50 months had a both $\mathrm{T} 2$ stage while the patients still alive had a T1 and T2 stage respectively.

\section{Conclusions}

In patients with Klatskin tumors, extensive resections including the liver parenchyma and even the main hepatic vessels bring a clearly benefit in terms of survival, thus it leads to an increase in postoperative morbidity and mortality. However, postoperative complications, if managed susccesfully do not interfere with the prognosis. Therefore, the only factors involved in the long-term survival of patients with $\mathrm{HC}$ remain the radical surgical excision and the tumor characteristics and stage.

\section{References}

1. Klatskin G. Adenocarcinoma of the hepatic duct at its bifurcation within the porta hepatis: an unusual tumor with distinctive clinical and pathologic features. Am J Med. 1965;38:241-256

2. Deoliveira M, Schulick R, Nimura Y, Rosen C, Gores G, Neuhaus P, et al. New staging system and a registry for perihilar cholangiocarcinoma. Hepatology. 2011;53:1363-71.

3. Konstandoulakis MM, Roayale S, Gomatos IP et al. Aggressive surgical resection for hilar cholangiocarcinoma:is it justified? Audit of a single center's experience. Am J Surg 2008;196;160-169

4. Hartog H, ljzermans JNM, van Gulik TM,Koerkamp BG. Resection of perihilar cholangiocarcinoma. Surg Clin N Am.2016;96:247-267

5. Van Gulik TM, Ruys A, Busch ORC, Rauws EJ, Gouma DJ. Extent of liver resection for hilar cholangiocarcinoma (Klatskin tumor): how much is enough? Dig Surg. 2011; 28: 141-147.

6. Groot Koerkamp B, Wiggers JK, Allen PJ, Besselink MG, Blumgart $\mathrm{LH}$, Busch OR et al. Recurrence Rate and Pattern of Perihilar Cholangiocarcinoma after Curative Intent Resection. J Am Coll Surg. 2015; 221:1041-1049.

7. Kawasaki S, Imamura H, Kobayashi $A$ et al. Results of surgical resection for patients with hilar bile duct cancer: application of 
extended hepatectomy after biliary drainage and hemihepatic portal vein embolization. Ann Surg 2003;238:84-92

8. Farges 0 , Regimbeau JM, Fuks D, Le Treut YP, Cherqui D et al. Multicentre European study of preoperative biliary drainage for hilar cholangiocarcinoma. Br J Surg. 2013;100:274-283

9. Spolverato G, Yakoob MY, Kim Y, Alexandrescu S, Marques HP et al. Impact of complications on long-term survival after resection of intrahepatic cholangiocarcinoma. Cancer. 2015 Aug 15;121(16):2730-2739

10. Ribero D, Amisano M, Lo Tesoriere R, Rosso S, Ferrero A, Capussotti L. Additional resection of an intraoperative margin-positive proximal bile duct improves survival in patients with hilar cholangiocarcinoma. Ann Surg. 2011;254:776-781

11. Bismuth $\mathrm{H}$, Corlette MB. Intrahepatic cholangioenteric anastomosis in carcinoma of the hilus of the liver. Surg Gynecol Obstet 1975;140:170-178

12. Strasberg SM, Phillips C. Use and dissemination of the brisbane 2000 nomenclature of liver anatomy and resections. Ann Surg. 2013:257:377-382

13. Dindo D, Demartines N, Clavien PA. Classification of surgical complications: a new proposal with evaluation in a cohort of 6336 patients and results of a survey. Ann Surg. 2004;240:205-213

14. Edge SB, Byrd DR, Compton CC, Fritz AG, Greene FL, Trotti A (editors). Perihilar bile ducts. In: American Joint Committee on Cancer: AJCC Cancer staging manual. 7th ed. New York, Dordrecht, Heidelberg, London; Springer;2010:219-225

15. Schwab M (editor). Broder Histological Classification. In: Encyclopedia of Cancer. Berlin Heidelberg; Springer; 2011:571

16. Kuvshinoff BW, Armstrong JG, Fong Y, Schupak K, Getradjman G, Heffernan $\mathrm{N}$ et al. Palliation of irresectable hilar cholangiocarcinoma with biliary drainage and radio- therapy. $\mathrm{Br} J$ Surg. 1995:82:1522-1525.

17. Saxena A, Chua TC, Chu FC, Morris DL. Improved outcomes after aggressive surgical resection of hilar cholangiocarcinoma: a critical analysis of recurrence and survival. Am J Surg. 2011;202:310-320

18. Wang ST, Shen SL, Peng BG, Hua YP, Chen B, Kuang M et al. Combined vascular resection and analysis of prognostic factors for hilar cholangiocarcinoma. Hepatobiliary Pancreat Dis Int. 2015; 14:626-632.

19. Yu W, Shao M, Gu Z, Shi S, Shen N, Zhang Y. Effect evaluation of vascular resection for patients with hilar cholangiocarcinoma: original data and meta-analysis. Hepatogastroenterology. 2014;61:307-313

20. Neuhaus P, Thelen A, Jonas S, Puhl G, Denecke T, Veltzke-Schlieker $W$ et al. Oncological superiority of hilar en bloc resection for the treatment of hilar cholangiocarcinoma. Ann Surg Oncol.
2012;19:1602-1608

21. Nagino M, Ebata T, Yokoyama Y, Igami T, Sugawara G, Takahashi Y et al. Evolution of surgical treatment for perihilar cholangiocarcinoma: a single-center 34-year review of 574 consecutive resections. Ann Surg. 2013;258:129-140

22. Nuzzo G, Giuliante F, Ardito F, Giovannini I, Aldrighetti L, Belli G et al. Improvement in perioperative and long-term outcome after surgical treatment of hilar cholangiocarcinoma: results of an Italian multicenter analysis of 440 patients. Arch Surg. 2012;147:26-34

23. Baton 0, Azoulay D, Adam DV, Castaing D. Major hepatectomy for hilar cholangiocarcinoma type 3 and 4: prognostic factors and longterm outcomes. J Am Coll Surg. 2007;204:250-260

24. DeOliveira ML, Cunningham SC, Cameron JL, Kamangar F, Winter JM, Lillemoe KD et al. Cholangiocarcinoma: thirty-one-year experience with 564 patients at a single institution. Ann Surg. 2007; $245: 755-762$

25. Han Liu, Xi Cen, Tao Suo, Xueya Cai, Xuewen Yuan, Sheng Shen et al. Trends and Hospital Variations in Surgical Outcomes for Cholangiocarcinoma in New York State. World J Surg. 2017;41:525-537

26. Soares KC, Kamel I, Cosgrove DP, Herman JM, Pawlik TM. Hilar cholangiocarcinoma: diagnosis, treatment options, and management. Hepatobiliary Surg Nutr. 2014;3:18-34

27. Loehrer AP, House MG, Nakeeb A, Kilbane EM, Pitt HA. Cholangiocarcinoma: are North American surgical outcomes optimal? J Am Coll Surg. 2013;216:192-200

28. Bhardwaj N, Garcea G, Dennison AR, Maddern GJ. The Surgical Management of Klatskin Tumours: Has Anything Changed in the Last Decade? World J Surg. 2015;39:2748-56

29. Miyazaki M, Shimizu H, Ohtuka M, Kato A, Yoshitomi H, Furukawa $\mathrm{K}$ et al. Portal vein thrombosis after reconstruction in 270 consecutive patients with portal vein resections in hepatopancreatobiliary (HPB) surgery. Am J Surg. 2016 Dec 24. pii: S00029610(16)31102-3 doi: 10.1016/j.amjsurg.2016.12.008. [Epub ahead of print].

30. Kow AW, Wook CD, Song SC, Kim WS, Kim MJ, Park HJ et al. Role of caudate lobectomy in type III A and III B hilar cholangiocarcinoma: a 15-year experience in a tertiary institution. World $\mathrm{J}$ Surg. 2012;36:1112-21

31. Popescu I, Dumitrascu T. Curative-intent surgery for hilar cholangiocarcinoma: prognostic factors for clinical decision making. Langenbecks Arch Surg. 2014;399:693-705

32. Ito F, Agni R, Rettammel RJ, Been MJ, Cho CS, Mahvi DM, Rikkers LF. Resection of hilar cholangiocarcinoma: concomitant liver resection decreases hepatic recurrence. Ann Surg. 2008:248:273-9 